\title{
Temperature-modulated DSC study of network formation via Thiol-Isocyanate "click" reaction
}

- Nguyen Tran Ha ${ }^{1}$

- Nguyen Thi Le Thu ${ }^{2}$

- Le Van Thang ${ }^{1}$

- Le Lam ${ }^{1}$

${ }^{1}$ Materials Technology Key Laboratory (Mtlab), Ho Chi Minh City University of Technology, VNUHCM.

${ }^{2}$ Faculty of Materials Technology, Ho Chi Minh City University of Technology, VNU-HCM.

(Manuscript Received on September 10 ${ }^{\text {th }}, 2015$, Manuscript Revised March 29 ${ }^{\text {th }}, 2016$ )

\section{ABSTRACT}

The thiol-isocyanate chemistry was used to characterize the occurrence of the networks create crosslinked polymer networks without the use of solvent and catalyst. The preliminary study of a model thiol-isocyanate reaction was performed to confirm the "efficient linking" feature of the reaction, as indicated by online FTIR method. Temperature-modulated differential scanning calorimetry (TMDSC) was used to

thiol-isocyanate reaction between multifunctional reactants, the influence of temperature on the reaction rate and the glass transition temperatures of the partially and fully cured networks. The investigation could pave the way for the design and tailoring of new cross-linked polymer materials for on-demand applications.

Key words: Temperature-modulated DSC, thiol-isocyanate, click reaction.

\section{INTRODUCTION}

Many polymerization reactions used to constitute polymer networks are complex and often require an initial resin formulation that undergoes a rapid transition from a relatively low viscosity liquid state to a highly crosslinked, glassy solid state with corresponding changes in different material properties. The ability to react and form networks with intimate control of the cross-linking dynamics and the final material properties has enabled their use across various fields and contributed to many technological advancements [1]. The broad spectrum of applications in which polymer networks have become important vary from automobile and aircraft parts to biomedical devices to lithographic imprint materials and optical devices [2]. In this respect, network formation taking advantage of the powerful capabilities afforded

\section{Trang 78}


by the "click" reaction paradigm has recently attracted significant attention [3,4]. Various examples of "click" reactions that have been employed as cross-linking pathways are copper (I)-catalyzed azide alkyne cycloaddition, photoinitiated thiol-ene, base-catalyzed thiol-ene Michael addition, and base-catalyzed thiolisocyanate reactions $[1,5]$.

The base-catalyzed reaction of thiols with isocyanates to form thiourethanes has been known for over 50 years, but has only recently been recognized for its potential as a click reaction [6-9]. Recently, the utilization of the thiol-isocyanate nucleophilic addition reaction between a tetrathiol and an diisocyanate to yield highly cross-linked and uniform molecular networks has shown great promise in the preparation of thermoset films or in healing cracked epoxy thermosets [10-14] owing to its simplicity and high efficiency. Especially, catalyst-free reactions of mono-functional thiols with mono-functional isocyanates have also been reported [15].

A prerequisite in developing new crosslinked polymer networks is understanding the curing kinetics in order to successfully design and tailor materials for on-demand applications. Therefore, in this paper, we studied the kinetic aspect of the networks stoichiometric reaction between the tetrafunctional thiol pentaerythritol tetrakis(3-mercaptopropionate) (tetrathiol) and hexamethylene diisocyanate (HDI) as a function of temperature without addition of any catalyst via the temperature-modulated differential scanning calorimetry method (TMDSC). TMDSC subjects a sample to a linear heating ramp with a superimposed low-frequency temperature oscillation (modulation) resulting in a modulation in the heating profile [16]. TMDSC analysis provides the "total" heat flow, such as that from conventional DSC, and the heat capacity-related (reversible) component of the heat flow. The difference between the reversing signal and the total is the non-reversing component. The reversing signal is excellent for quantifying the glass transition and separates the glass transition completely from other nonreversing processes such as enthalpy relaxation, crystallization, and cure reaction-related enthalpy changes [16]. To the best of our knowledge, a calorimetric study of a catalyst-free thiolisocyanate curing mixture has not been previously reported.

\section{EXPERIMENTAL}

\subsection{Materials}

Hexamethylene diisocyanate (HDI, $\geq 99 \%$ ), pentaerythritol tetrakis(3-mercaptopropionate) (tetrathiol, >95\%), isooctyl 3mercaptopropionate (>99\%) and hexyl isocyanate (>97\%) were purchased from SigmaAldrich and used as received.

\subsection{Kinetic investigation of stoichiometric} reactions between thiols and isocyanates

To investigate the stoichiometric reaction between mono-functional thiol and monofunctional isocyanate, isooctyl 3mercaptopropionate was mixed with hexyl isocyanate (molar ratio between the thiol and isocyanate functional groups of 1) and the reaction was performed at $90 \mathrm{oC}$ under stirring, and was simultaneously monitored using the time-resolved online ATR FT-IR method.

To investigate the stoichiometric networks reaction between the tetrathiol and HDI, a wellmixed (for 15 seconds at room temperature) mixture of tetrathiol and HDI, with the molar ratio between the thiol and isocyanate functional 
groups of 1, was subjected to TMDSC measurements.

\subsection{Characterization}

Time-resolved online ATR FT-IR spectra were recorded on a React-IR 4000 Instrument (Mettler Toledo AutoChem ReactIR) equipped with a silicon ATR probe (SiComp). For online monitoring, the silicon probe was introduced into a two-necked glass flask containing the reaction mixture (the IR probe was in contact with the reaction liquid) under stirring at $90^{\circ} \mathrm{C}$ and spectra were recorded for certain time intervals.

Temperature-modulated differential scanning calorimetry (TMDSC) thermograms were recorded using a TA-Instruments T-MDSC 2920 instrument. Nitrogen gas was used as purge gas. Liquid nitrogen was used to cool the system. The samples were studied in standard $40 \mu \mathrm{L}$ aluminum sample pans and at a scan rate of 2.5 $\mathrm{K} \min -1$.

\section{RESULTS AND DISCUSSION}

In order to confirm the reaction between the isocyanate and thiol groups at elevated temperatures, the reaction of a liquid stoichiometric mixture of hexyl isocyanate and isooctyl 3-mercaptopropionate as monofunctional isocyanate and mono-functional thiol, respectively, was investigated (Scheme 1). The kinetics of the reaction between hexyl isocyanate and isooctyl 3-mercaptopropionate at $90^{\circ} \mathrm{C}$ was studied with in situ FT-IR by real-time monitoring of the peak areas of the $\mathrm{S}-\mathrm{H}$ stretch at $2582 \mathrm{~cm}^{-1}$ and $\mathrm{NCO}$ stretch at $2266 \mathrm{~cm}^{-1}$ as well as the formed thiourethane (NHCOS) $\mathrm{C}=\mathrm{O}$ stretch at 1687-1660 cm-1. 3D online FT-IR waterfall plots showing the evolution of characteristic IR peaks for the thiolisothiocyanate reaction between isooctyl 3mercaptopropionate and hexyl isocyanate are given in Figure 1a. The occurrence of the reaction is indicated by decreases in the IR absorption intensities of the thiol and isocyanate bands and an increase in the intensity of the thiourethane band. In Figure 1b, the FT-IR band intensities, reflecting the concentrations of the reactants and the product (thiourethane) as a function of time, are shown. The decrease of the areas of the S-H stretch and the isocyanate $\mathrm{C}=\mathrm{O}$ stretch were used to establish the kinetic profile. As shown in Figure 1b, simultaneous and equimolar consumption of the thiol and isocyanate was observed, indirectly suggesting that the reaction was clean and efficient. However, it is worth noted that side reactions, such as dimerization and trimerization of isocyanate, were not fully excluded, although it was not very likely without any catalyst [17]. Almost full conversion was obtained after $12 \mathrm{~min}$.

\section{Trang 80}




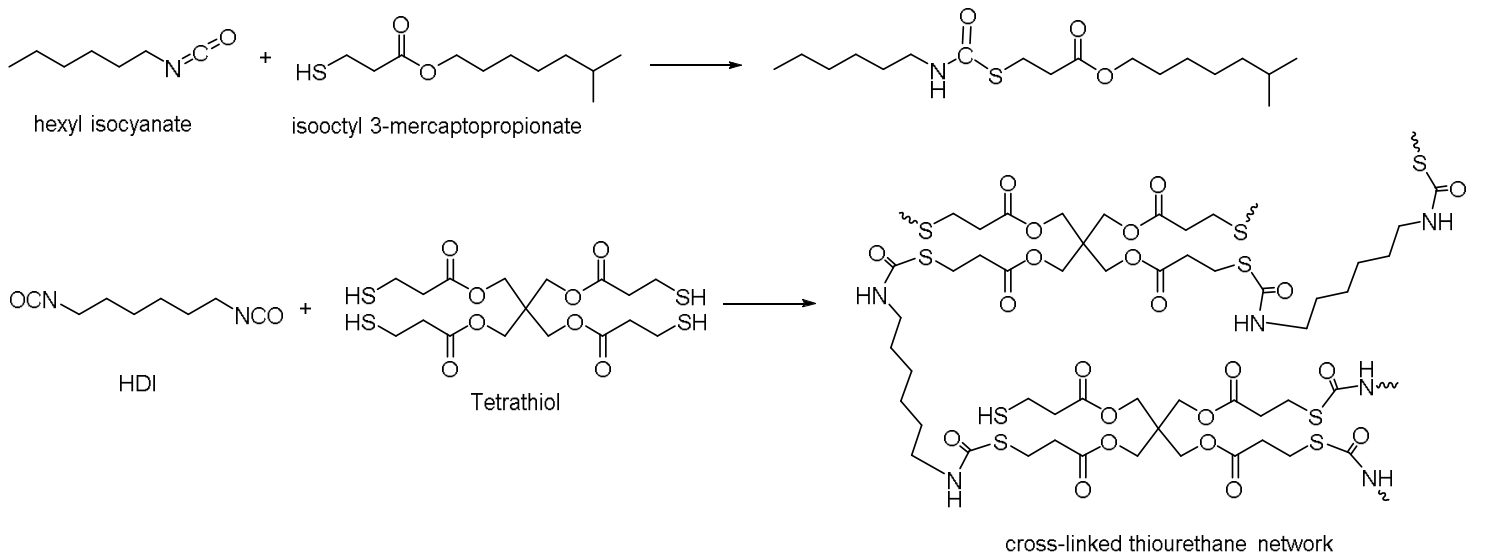

Scheme 1. Thiol-isocyanate reaction of model mono-functional compounds and that between tetrathiol and HDI to form a crosslinked network.

(a)

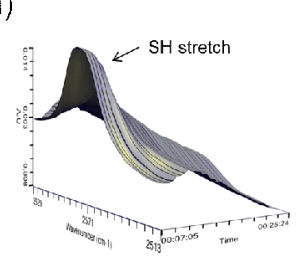

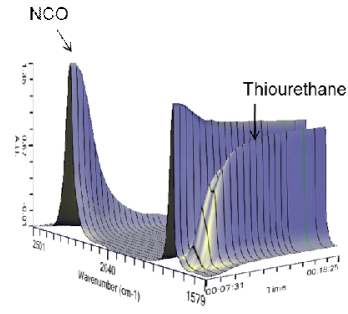

(b)

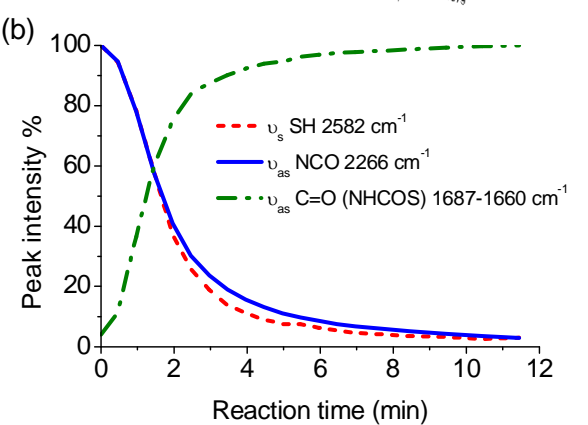

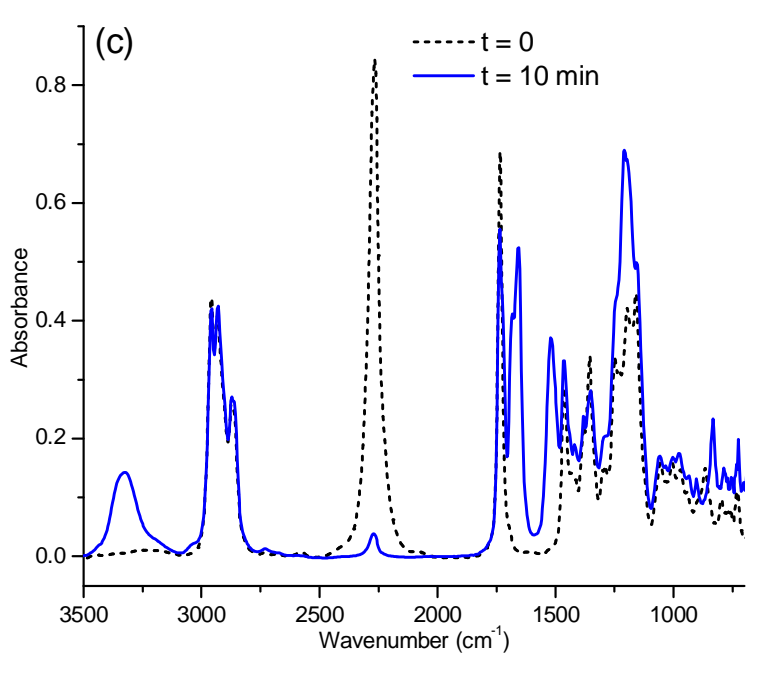

Figure 1. (a) 3D online FT-IR waterfall plots, showing the evolution of characteristic IR peaks for the thiolisothiocyanate reaction between isooctyl 3-mercaptopropionate and hexyl isocyanate, (b) band intensities of thiol, isocyanate and thiourethane as a function of time reflecting the kinetic profile, and (c) a comparison of the full FT-

IR spectra of the reaction at the start and after $10 \mathrm{~min}$.

After the model study, the cross-linking reaction between tetrathiol and HDI was investigated by DSC. A non-isothermal DSC experiment showed that while heating the reactive mixture at a constant heating rate of 2.5 $\mathrm{K} \min ^{-1}$, the reaction started at a temperature of about $18^{\circ} \mathrm{C}$ (Figure 2). The reaction was evidenced by a clear exothermic peak ranging from $18^{\circ} \mathrm{C}$ to about $150^{\circ} \mathrm{C}$. The reaction was not finished at the time when the temperature reached $150^{\circ} \mathrm{C}$. Upon cooling, the DSC curve (Figure 2) was still largely curved in the exothermic direction which is likely explained by the ongoing reaction. A glass transition at about $10^{\circ} \mathrm{C}$ of the reacted system was observed, which was also the case of the second heating step. The 
second heating curve still showed evidence of ongoing reaction as the curve dropped in endothermic direction.

Since the curing reaction has not been complete at $150^{\circ} \mathrm{C}$, the reaction was further investigated up to $190^{\circ} \mathrm{C}$ by TMDSC (Figure 3). The result shown in Figure 3 indicates that the reaction was nearly complete. The exotherm ranging from 18 to $170^{\circ} \mathrm{C}$ in the first heating scan did not appear in the reversing heating flow because the curing process was non-reversing. On the other hand, the glass transition was around $24^{\circ} \mathrm{C}$ in the subsequent second heating scan. The glass transition temperature was shifted to $38^{\circ} \mathrm{C}$ in the third scan, and did not change upon further heating-cooling scans. The higher glass transition temperature $\left(38^{\circ} \mathrm{C}\right)$ as compared to that $\left(-10^{\circ} \mathrm{C}\right)$ in Figure 2 is attributed to the higher reaction conversion upon extending the reaction temperature to $190^{\circ} \mathrm{C}$.

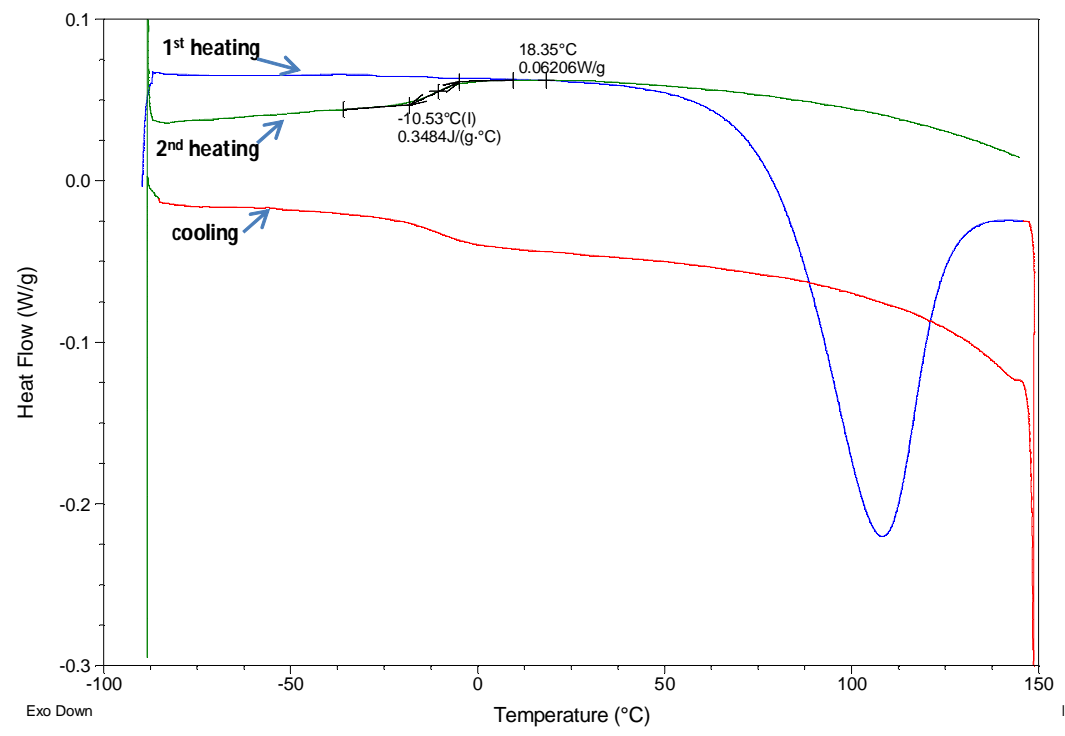

Figure 2. Non-isothermal DSC measurement at $2.5 \mathrm{~K} \mathrm{~min}^{-1}$ from -80 to $150^{\circ} \mathrm{C}$ of a stoichiometric mixture of tetrathiol and HDI.

\section{Trang 82}




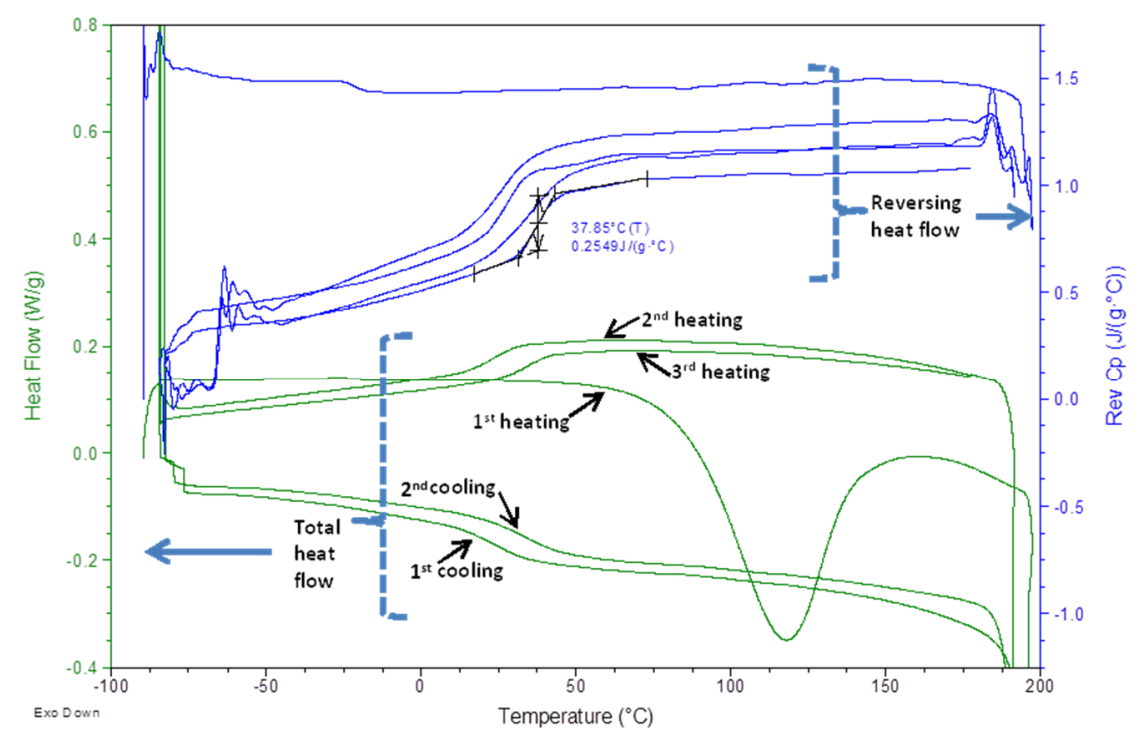

Figure 3. Non-isothermal DSC measurement at $2.5 \mathrm{~K} \mathrm{~min}^{-1}$ from -80 to $190^{\circ} \mathrm{C}$ of a stoichiometric mixture of tetrathiol and HDI (only heating scans are shown for reversing heating capacity).

To further investigate the curing thiolisocyanate reaction, a series of isothermal measurements has been performed on the system (Figure 4). The heat flow signal of each measurement shows exothermic signals originating from the reactions. Upon increasing the isothermal temperature, the reaction rates were increased considerably (the maximum peak height was obtained after more than $90 \mathrm{~min}$ at $60^{\circ} \mathrm{C}$ whereas only a few minutes at temperatures above $90^{\circ} \mathrm{C}$ ). The total heat of the reaction was about 300J g-1.

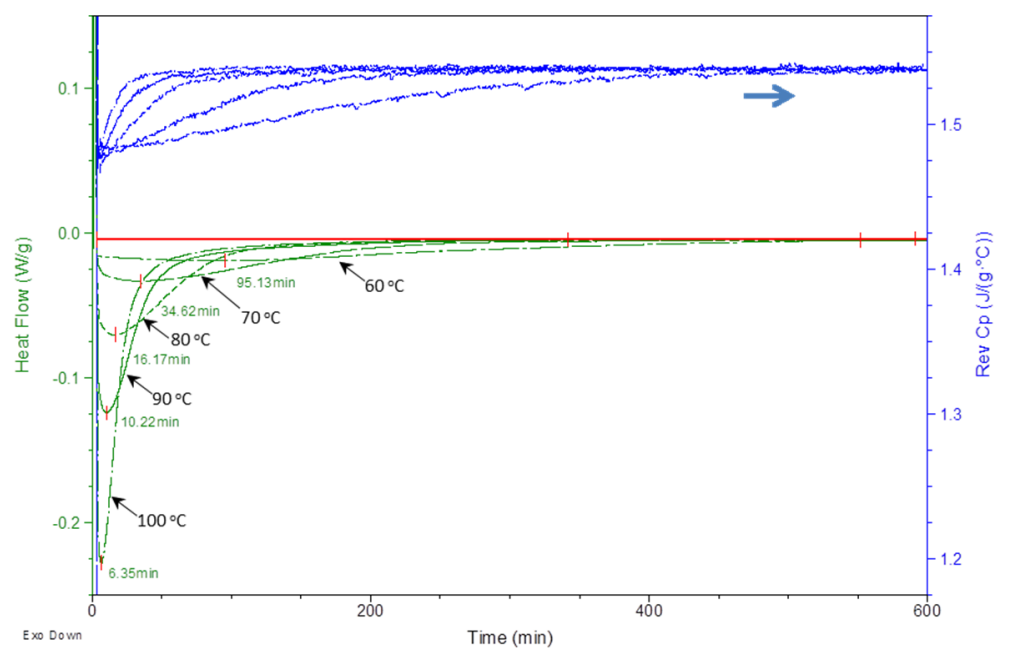

Figure 4. Isothermal TMDSC measurements at various temperatures of the stoichiometric mixture of tetrathiol and HDI. 
After the isothermal TMDSC measurements, a series of heating and cooling cycles were performed. The first cycle was performed in order to investigate residual reaction. This could be due to time limitation. The second and third additional cycles were used to evaluate the final glass transition of the network, considering that the reaction has been complete. Figure 5 shows the additional heating scans (3 cycles) of the isothermal TMDSC measurements. From the first cycle DSC curves, the glass transition temperatures of the partially cured networks right at the end of the isothermal measurements range from about $-10^{\circ} \mathrm{C}$ to almost $25{ }^{\circ} \mathrm{C}$. Because the glass transition temperature of a thermosetting polymer system increases with increasing reaction conversion, this DSC result indicates that higher reaction conversions were obtained for isothermal DSC measurements at higher temperatures. On the other hand, the additional cycles after the second cycles for all samples almost overlapped with one another, showing one glass transition. Because the glass transition temperatures appeared the same in the third and second DSC scans (regarding the sample previously cured at $100^{\circ} \mathrm{C}$ ), no further DSC scan was conducted. The main conclusion that can be drawn is the confirmation of the final glass transition temperature of about $35-38^{\circ} \mathrm{C}$.

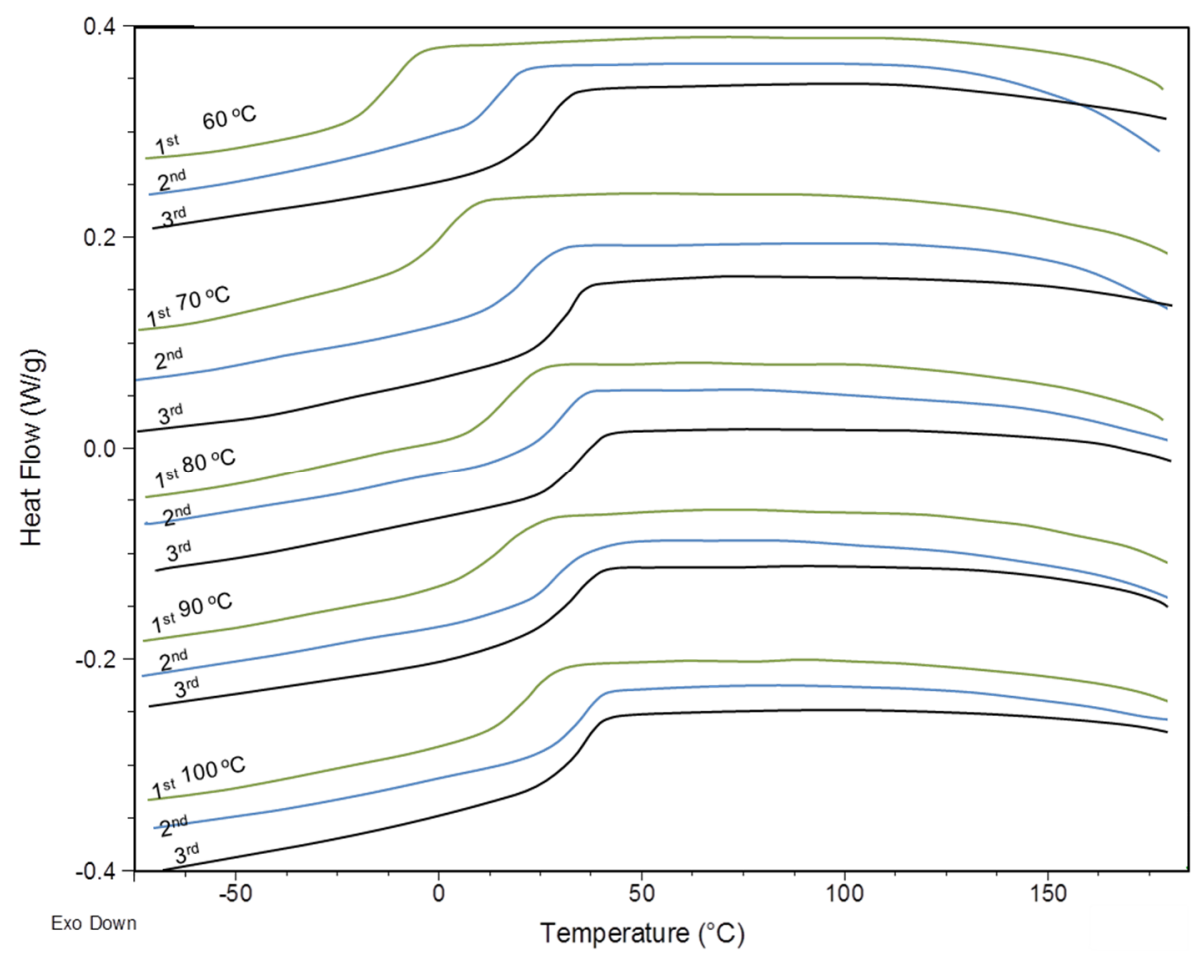

Figure 5. DSC heating scans after isothermal TMDSC measurements at different temperatures $\left(60-100{ }^{\circ} \mathrm{C}\right.$, previously shown in Figure 4).

\section{Trang 84}




\section{CONCLUSIONS}

The kinetics of the model stoichiometric reaction between mono-functional thiol and isocyanate as well as the cross-linking reaction between a tetrathiol and diisocyanate were investigated, using in situ FT-IR and temperaturemodulated DSC methods, respectively. The TMDSC analysis of the curing system showed that the thiol-isocyanate reaction was complete by heating at $2.5 \mathrm{~K} \mathrm{~min}^{-1}$ up to $170^{\circ} \mathrm{C}$. The glass transition temperature of the cured system increased with increasing reaction conversion. The total heat of the reaction was about $300 \mathrm{~J} \mathrm{~g}^{-1}$.
Isothermal heating of the reactant mixture at various temperatures from 60 to $100^{\circ} \mathrm{C}$ yielded partially cross-linked materials with glass transition temperatures varying from -10 to $25^{\circ} \mathrm{C}$. The glass transition temperature of the finally cured system was found to be around $38^{\circ} \mathrm{C}$.

Acknowlegments: This research was supported by project "TX2015-20-06/HÐKHCN" from Ho Chi Minh City University of Technology - Vietnam National University - Ho Chi Minh City, 268 Ly Thuong Kiet, District 10, Ho Chi Minh City, Viet Nam. 


\section{Nghiên cứu chuyển biến nhiệt bằng phương pháp DSC của sự hình thành mạng bằng phản ứng “click” thiol-isocyanate}

- Nguyễn Trần Hà ${ }^{1}$

- Nguyễn Thị Lệ Thu ${ }^{2}$

- Lê Văn Thăng ${ }^{1}$

- Lê Lâm ${ }^{1}$

${ }^{1}$ Phòng Thí nghiệm trọng điểm Đại học Quốc Gia Công Nghệ Vật Liệu

${ }^{2}$ Khoa Công Nghệ Vật Liệu, Trường Đại học Bách Khoa, ĐHQG-HCM

\section{TÓM TẮT}

Hóa hoc "click" thiol-isocyanate dươc sủ dụng để tạo ra hệ polymer nối mạng mà không sủ dụng dung môi và chất xúc tác. Khảo sát ban đầu, bà̀ng phwong pháp online FT-IR, mô hình phản úng thiol-isocyanate được thực hiện để xác nhận các đặc trung của phản úng "Click”, nhằm khăng định đặc tính "click" của phản úng. Phuoong pháp "temperature-modulated differential scanning calorimetry" (TMDSC) đã được sủ̉ dụng để nghiên cúu đánh giá quá đặc tính quá trình và động hoc của phản úng nối mạng thiol-isocyanate giũa các chất phản úng đa chưc, cũng nhu sụ chuyển pha thủy tinh của mang polyme tạo thành. Theo sụ hiểu biết của chúng tôi, nghiên cúu nhiệt luợng của hệ nối mạng thiol-isocyanate không chất xúc tác chua tùng được công bố trước đây. Các kết quả này có thể mở đuò̀ng cho việc thiết kế và chế tạo các vật liệu polymer nhiệt rắn mói đáp úng nhiều úng dụng theo yêu cầu.

Tù khóa: Temperature-modulated DSC, thiol-isocyanate, click reaction.

\section{REFERENCES}

[1]. Hoyle, C. E., Bowman, C. N., Angew. Chem. Int. Ed., 2010, 49, 1540.

[2]. Chan, J. W., Hoyle, C. E., Lowe, A. B., Bowman, M., Macromolecules, 2010, 43, 6381.

[3]. Nair, D. P., Podgórski, M., Chatani, S., Gong, T., Xi, W., Fenoli, C. R., Bowman, C. N., Chem. Mater., 2014, 26, 724-744.
[4]. Kolb, H. C., Finn, M. G., Sharpless, K. B., Angew. Chem. Int. Ed., 2001, 40, 2004.

[5]. Kempe, K., Krieg, A., Becer, C. R., Schubert, U. S., Chem. Soc. Rev., 2012, 41, 176-191.

[6]. Hoyle, C. E., Lowe, A. B., Bowman, C. N., Chem. Soc. Rev., 2010, 39, 1355-1387.

[7]. Arnold, R. G., Nelson, J. A., Verbanc, J. J., Chem. Rev., 1957, 57, 47-76.

\section{Trang 86}


[8]. Hensarling, R. M., Rahane, S. B., LeBlanc, A. P., Sparks, B. J., White, E. M., Locklin, J., Patton, D. L., Polym. Chem., 2011, 2, 88-90.

[9]. Nguyen, L.-T. T., Gokmen, M. T., Du Prez, F. E., Polym. Chem., 2013, 4, 5527-5536.

[10].Li, Q., Zhou, H., Wicks, D. A., Hoyle, C. E., J. Polym. Sci., Part A: Polym. Chem., 2007, 45, 5103-5111.

[11].Billiet, S., Hillewaere, X. K. D., Teixeira, R. F. A., Du Prez, F. E., Macromol. Rapid Commun., 2013, 34, 290-309.

[12].Hillewaere, X. K. D., Du Prez, F. E., Prog. Polym. Sci., 2015, doi:10.1016/j.progpolymsci.2015.1004.1004
[13].Shin, J., Matsushima, H., Comer, C. M., Bowman, C. N., Hoyle, C. E., Chem. Mater., 2010, 22, 2616-2625.

[14].Matsushima, H., Shin, J., Bowman, C. N., Hoyle, C. E., J. Polym. Sci., Part A: Polym. Chem., 2010, 48, 3255-3264.

[15].Movassagh, B., Soleiman-Beigi, M., Monatshefte für Chemie - Chemical Monthly, 2008, 139, 137-140.

[16]. Verdonck, E., Schaap, K., Thomas, L. C., Int. J. Pharm., 1999, 192, 3-20.

[17].Saunders, J. H., Frisch, K. C, In Polyurethanes: Chemistry and Technology. Part I, Chemistry; Interscience: New York, 1962; Chapters 1-4. 